\title{
Pengaruh Kewirausahaan Terhadap Pertumbuhan Usaha Peternakan Ayam Broiler Pola Mandiri di Kabupaten Lima Puluh Kota
}

\author{
Ridha Yatni ${ }^{1 *}$, Rachmat Pambudy ${ }^{2}$, Burhanuddin ${ }^{2}$ \\ ${ }^{1}$ Program Studi Sains Agribisnis Fakultas Ekonomi Manajemen, Sekolah Pascasarjana \\ Institut Pertanian Bogor \\ ${ }^{2}$ Fakultas Ekonomi dan Manajemen, Institut Pertanian Bogor \\ Jln. Raya Dramaga, Kampus IPB Dramaga, Bogor 16680 \\ *Email korespondensi: yatniridha@gmail.com
}

(Diterima: 28-06-2019; disetujui 16-08-2019)

\begin{abstract}
ABSTRAK
Sumatera barat yang merupakan salah satu sentra produksi peternakan ayam broiler. Selain itu daging ayam broiler merupakan konsumsi tertinggi daripada daging sapi maupun daging ayam kampung. Namun pada tahun 2017 terjadi penurunan produksi ayam broiler sebesar 0,21 persen. Hal ini menggambarkan adanya masalah aktivitas kewirausahaan terutama pada peternakan mandiri yang lebih rentan terhadap ketidakstabilan harga dipengaruhi oleh daya produksi, inovasi dan daya saing dalam melakukan usahanya. Oleh karena itu penelitian ini bertujuan untuk menganalisis pengaruh aktivitas kewirausahaan terhadap pertumbuhan usaha peternakan mandiri. Metode analisis yang digunakan adalah Partial Least Square (PLS). Data primer diperoleh dari wawancara menggunakan kuisioner. Data sekunder diperoleh dari literatur terkait. Hasil penelitian menujukan daya produksi dan daya saing tidak berpengaruh signifikan. Sedangkan inovasi berpengaruh signifikan sebesar 0.368. Artinya penting adanya usaha yang inovasi dan kreatif seperti penggunaan metode berproduksi baru. Variabel laten aktivitas kewirausahaan berpengaruh positif dan signifikan terhadap pertumbuhan usahanya sebesar 0.330. Saran agar pemerintah dapat mempercepat pertumbuhan usaha dengan mengadakan pelatihan dan penyuluhan yang mendorong pertumbuhan usaha dilihat dari pendapatan dan skala usaha.
\end{abstract}

Kata Kunci: inovasi, partial least square (PLS), peternakan ayam broiler, pertumbuhan usaha, pola mandiri

\begin{abstract}
West Sumatra which is one of the centers of broiler chicken production. In addition broiler chicken meat is the highest consumption than beef or chicken meat. But in 2017 there was a decrease in broiler chicken production by 0.21 percent. This illustrates the problem of entrepreneurial, especially in independent farms which are more susceptible to price instability influenced by the power of production, innovation, and competitiveness in doing business. Therefore this study aims to analyze the influence of entrepreneurial activity on the growth of independent livestock businesses. The analysis method used is PLS. Primary data were obtained from interviews using questionnaires. Secondary data were obtained from the relevant literature. The results of the research addressing the power of production and competitiveness have no significant effect. While innovation has a significant effect of 0.368 . It means that there is an innovation and creative effort such as the use of new production methods. The latent variable of entrepreneurial has a positive and significant effect on business growth of 0.330 . Suggestions that the government can accelerate business growth by holding training and counseling that encourage business growth seen from income and business scale.
\end{abstract}

Keywords: broiler, business growth, independent pattern, innovation, PLS 


\section{PENDAHULUAN}

Wirausaha yang inovatif penting dalam daya saing ekonomi dan dapat membangun lapangan pekerjaan yang baru. Pengusaha mendorong pertumbuhan ekonomi memperkenalkan teknologi, produk dan layanan yang inovatif dan didukung dengan peraturan negara yang ramah inovasi (Kritikos, 2014). Adanya aktivitas kewirausahaan dapat mengurangi tingkat pengangguran, meningkatkan pendapatan dan poduktivitas usaha (Faturohman et al., 2007). Oleh karena itu pentingnya aktivitas kewirausahaan dikembangkan dalam suatu daerah. Aktivitas kewirausahaan ini dapat ditemui pada peternakan ayam broiler (Burhanuddin, 2014).

Sumatera Barat termasuk kedalam lima sentra pengahasil daging ayam broiler. Namun, dari tahun 2016 ke tahun 2017 mengalami penurunan pertumbuhan produksi sebesar 0,21 persen. Dari data juga terlihat bahwa pola konsumsi makanan penduduk Provinsi Sumatera Barat terhadap daging ayam broiler mengalami peningkatan dari tahun sebelumnya. Hal ini di dukung oleh Tamalluddin (2012), bahwa penyerapan terbesar daging ayam broiler sebanyak 80 persen digunakan dalam pengolahan makanan di restoran dan hotel sedangkan 5 persen oleh pasar modern dan 15 persen diserap oleh pasar tradisional.

Peternakan memang menjadi unggulan di Kabupaten Lima Puluh Kota yang merupakan sentra peternakan ayam broiler di Sumatera Barat dengan produksi dan populasi tertinggi. Beternak ayam broiler ini sangat berpotensi untuk dikembangkan tetapi dalam usaha ayam broiler ini juga memiliki tantangan yang umum bagi peternak seperti mudah stres, peka terhadap perubahan cuaca dan memerlukan pasokan nutrisi yang benar-benar sesuai dengan yang dibutuhkan, ancaman penyakit pada ternak dan keberhasilan usaha broiler ini juga ditentukan oleh faktor teknis seperti kualitas Day Old Chicks (DOC), manajemen peternakan yang baik serta harga $D O C$ yang berfluktuasi sehingga menyebabkan harga jual terhadap daging ayam broiler juga mengalami fluktuasi dan harga terhadap ayam broiler hidup mengalami penurunan setiap tahunnya. Oleh karena itu butuh keahlian peternak dalam menggabungkan seluruh inputnya untuk ushaternak sehingga menciptakan daya saing dan butuh juga inovasi yang lebih baik lagi.

Peternak mandiri merupakan sistem usaha ternak ayam broiler yang umumnya modal sepenuhnya dari peternak mulai dari penyediaan sarana produksi seperti pakan, DOC, obat-obatan dan sebagainya yang biasanya dibeli di kios-kios terdekat hingga pemasaran yang dilakukan juga mencari peluang pasar sendiri dan dapat memasarkan hasil produksinya kemana saja. Memiliki kelebihan dalam manajemen usahanya sesuai keinginan sendiri sehingga lebih leluasa memiliki kewenangan dalam melakukan usahanya. Namun permasalahan yang dihadapi dalam peternak mandiri ini selain pemasaran yang belum pasti ialah harga sarana produksi yang mengalami fluktuasi. Menurut Dinas Peternakan dan Kesehatan Hewan Kabupaten Lima Puluh kota (2017) jumlah peternakan mandiri meningkat 100 persen dari tahun 2015, hal ini menandakan minat masyarakat terhadap usaha pola mandiri cukup tinggi.

Pertumbuhan usaha dapat dilihat melalui perubahan tingkat pendapatan dan pertumbuhan skala usaha Pertumbuhan usaha pada penelitian Astuti (2016) bahwa indikator pertumbuhan pendapatan merupakan indikator yang paling kuat daripada skala usaha. Sedangkan dalam penelitian Burhanuddin (2014), terjadi peningkatan pada pendapatan dan skala usaha yang mendominasi pada usaha peternak ayam broiler. Menurut Naude (2008) bahwa perlunya pengamatan terhadap aktvitas kewirausahaan karena masuknya pengusaha dengan kemampuan rendah dapat menjadi penghambat pembangunan ekonomi. Sehingga dibutuhkan juga wirausaha yang berani berinovasi atau memiliki ide-ide kreatif yang dapat mengembangkan usaha ternak ayam broiler ini hal ini dibutuhkan karena adanya keterbatasan dalam usaha ayam broiler. Menurut Stough (2016), dukungan pemerintah juga diperlukan. Didukung Pambudy (2010), yang menegaskan bahwa menumbuhkan kewirausahaan dapat tercapai pada pemerintahan yang baik, bersih dan bervisi.

\section{MATERI DAN METODE}

\section{Kerangka Pemikiran}

Aktivitas kewirausahaan merupakan tindakan manusia dalam menambah nilai melalui penciptaan dan perluasan kegiatan ekonomi dengan mengidentifikasi dan memanfaatkan produk, proses atau pasar baru (Ahmad dan Seymor 2008). Proses kewirausahan menjelaskan bahwa organisasi merupakan faktor yang mendorong terjadinya pertumbuhan usaha. Bygrave \& Zachrakis (2010), 
menyatakan bahwa adanya tim akan terciptanya produktifitas usaha, memiliki strategi usaha, keistimewaan lokasi usaha dan budaya organisasi. Kerangka pemikiran operasional di adopsi dari teori Se Board Performance Committe (2008). Kerangka pemikiran dilihat pada Gambar 1.

\section{Jenis dan Sumber Data}

Terdiri dari data sekunder dan data primer. Data sekunder diperoleh dari berbagai sumber diantaranya data statistik dan jurnal atau hasil penelitian ilmiah, buku-buku literatur, disertasi, tesis, internet, data Dinas Peternakan Kabupaten Lima Puluh Kota dan data Badan Pusat Statistik. Data primer diperoleh dari responden melalui wawancara yang berpedoman pada kuesioner.
Alternatif jawaban disesuaikan dengan skala likert yang dibuat menjadi lima alternatif jawaban. Setiap variabel pengukuran diindikasikan oleh pernyataan dan setiap pernyataan dalam kuisioner diberi skala dengan menggunakan skala likert 1-5 dengan penjelasan sebagai berikut: $1=$ sangat tidak setuju; 2 = tidak setuju; $3=$ netral; $4=$ setuju; $5=$ sangat setuju. Populasi dari penelitian ini adalah semua peternakan ayam broiler pola mandiri yang ada di Kabupaten Lima Puluh Kota. Sampel responden yang digunakan dalam penelitian ini adalah peternakan ayam broiler pola mandiri diambil dengan teknik probability sampling yaitu stratified random sampling. Sampel dipilih secara random secara unproportional menjadi 60 peternak.

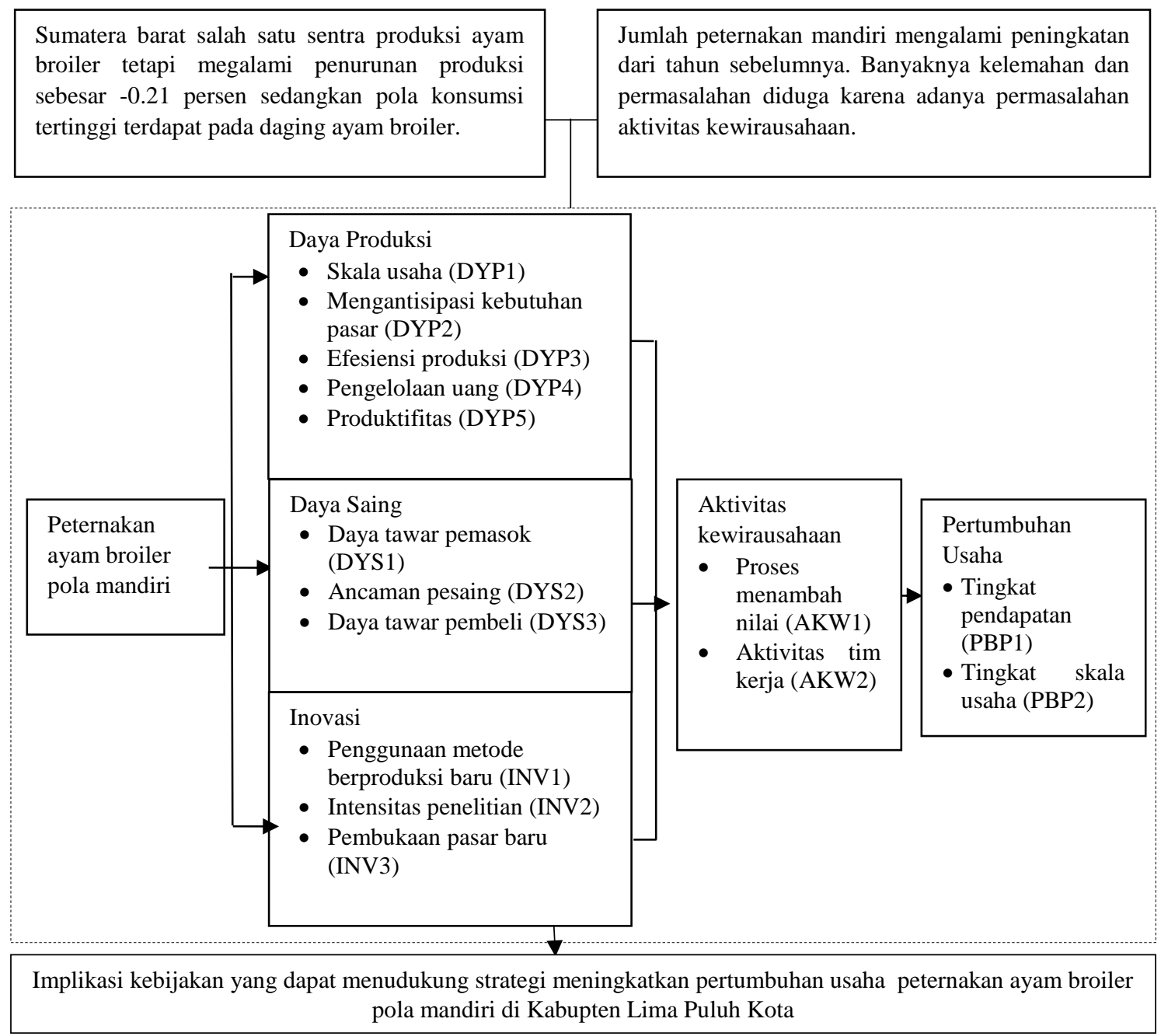

Gambar 1. Kerangka pemikiran operasional penelitian pengaruh aktivitas kewirausahaan peternakan terhadap pertumbuhan usaha 


\section{Analisis Data}

Analisis kuantitatif dilakukan menggunakan Partial Least Square (PLS) untuk melihat pengaruh aktivitas kewirausahaan terhadap pertumbuhan usaha. Data kuantitatif diolah dengan bantuan program microsoft excel dan dianalisis menggunakan pendekatan smart partial least square (PLS). Variabel laten (unobserved variable) adalah variabel yang tidak dapat langsung diamati, variabel ini dapat diamati dengan adanya bantuan variabel indikator (manifest). Variabel ini dilambangkan dan bentuk bulat atau elips yaitu

(O) sementara observed variable digambarkan dengan simbol kotak ( $\square$ ) digunakan untuk mengukur variabel laten, model evaluasi PLS berdasarkan pada pengukuran prediksi yang mempunyai sifat nonparametrik. Tahap dalam evaluasi model pengukuran terdiri dari dua outer model dan inner model. Untuk analisis data dan model persamaan structural dengan menggunakan software smart PLS menurut Ghozali \& Latan (2015):

\section{Pengukuran model (outer model)}

Bagaimana setiap blok indikator berhubungan dengan variabel latennya. Indikator refleksif yang menggunakan tiga kriteria untuk menilai outer model, yaitu:

Convergent Validity. Convergent Validity dinilai berdasarkan korelasi antara item score dengan construct score yang dihitung dengan PLS. Penelitian awal pengembangan skala pengukuran nilai loading 0,30 sampai dengan 0,60 dianggap cukup.

Composite Reliability. Mengukur reliabilitas suatu konstruk dengan indikator reflektif dapat dilakukan dengan dua cara yaitu disarankan untuk menggunakan CR. Titik kritis yang digunakan untuk menilai realibilitas dengan $\mathrm{CR}$ disarankan > 0,7 .

Discriminant Validity. Pengukuran dengan indikator refleksif dinilai berdasarkan cross loading pengukuran dengan konstruk. Jika nilai akar AVE setiap konstruk lebih besar daripada nilai korelasi antara konstruk dengan konstruk lainnya dalam model, maka dikatakan memiliki nilai discriminant validity yang baik.

2. Model struktural atau inner model

Pengujian inner model atau model struktural dilakukan untuk melihat hubungan antara konstruk. Model struktural dievaluasi dengan menggunakan
R-Square untuk konstruk dependen, Stone-Geisser$Q$ - Square test untuk predictive relevance dan uji-t untuk signifikansidari koefisien parameter jalur struktural serta overall fit index yang menggunakan GoF index. Melakukan pengujian hipotesis (Resampling Bootsraping). Kriteria untuk menolak dan menerima hubungan yang diajukan dapat dilihat dan dari perbandingan antar nilai t-hitung dan ttabel. Jika nilai t-hitung > t-tabel yaitu 1.96 maka H0 diterima. Hipotesis alternatif yang dinyatakan dalam penelitian ini diterima pada tingkat signifikansi 5 persen.

\section{HASIL DAN PEMBAHASAN}

\section{Model Aktivitas Kewirausahaan terhadap Pertumbuhan Usaha}

Penilaian model outer dilakukan dengan membandingkan loading factor dengan nilai standarnya yaitu 0.5 . selain itu juga dapat dilihat dari nilai berdasarkan model ini terdapat tiga indikator yang memiliki nilai loading factor dibawah 0,5 yaitu variabel skala usaha (DYP1), produktifitas (DYP5) dan daya tawar pemasok (DYS1), sehingga dilakukan validasi ulang untuk mendapatkan hasil yang terbaik dengan menghilangkan loading factor di bawah 0,5. Model setelah direestimasi dilihat pada Gambar 2.

\section{Model Struktural Inner Model}

Pada tahap kedua (inner model) dilakukan pengujian hipotesis (resampling bootsraping). Pengujian hipotesa peternakan mandiri dapat dilihat pada Tabel 1. Berdasarkan hasil pengujian hipotesa koefisien path dan P-values pada model peternakan pola mandiri pada taraf nyata 0,05 daya produksi berhubungan positif tetapi tidak signifikan dengan aktivitas kewirausahaan dengan p-values $0,420>0,05$ dan daya saing berhubungan negatif dan tidak signifikan dengan $p$-values $0,101>0,05$. Sedangkan pada variabel inovasi bepengaruh positif dan signifikan dengan $p$-values $0,003<0,05$. Hal ini menunjukan bahwa dengan adanya kewirausahaan pada peternakan pola mandiri yang didukung dengan inovasi di Kabupaten Lima Puluh Kota mempengaruhi pertumbuhan usahanya.

\section{Daya Produksi}

Daya produksi merupakan variabel laten yang menggambarkan kondisi kondisi internal usahanya dilihat dari daya produksi yang merupakan keseluruhan proses mengkombinasikan 


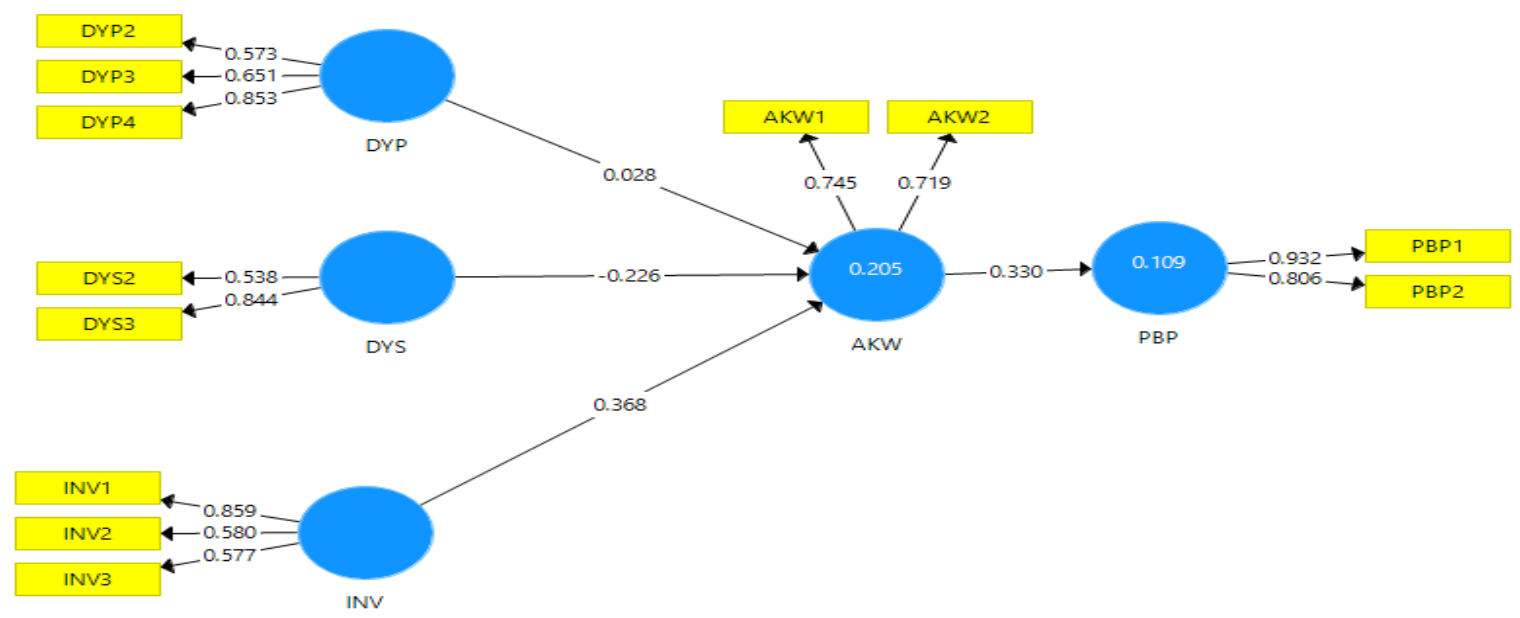

Gambar 2. Hasil analisis model setelah direestimasi pada peternak mandiri

Berbagai input untuk menghasilkan output. Indikator mengantisipasi kebutuhan pasar (DYP2) dapat menjelaskan daya produksi dengan nilai loading factor sebesar 0,573. Peternak memantau perkembangan harga pasar dan aktif mencari informasi dari sesama peternak maupun melewati media lain seperti internet dan televisi karena pada pola usaha ini mereka menjual hasil ternaknya sesuai dengan harga pasar. Hal ini sejalan dengan penelitian (Okpara, 2007) bahwa pentingnya me menuhi kebetuhan pasar dengan mengantisipasi kebutuhan pasar. Perencanaan pasar dilakukan bersama dengan poultry shop dan pedagang. Preferensi kesukaan konsumen cenderung menyukai ayam berumur <30 hari karena target pasarnya adalah rumah makan dan restoran.

Efesiensi produksi dapat menjelaskan daya produksi dengan nilai loading factor sebesar 0,651. Jika mereka bekerjasama dengan poultry shop pakan yang tidak terpakai akan diambil kembali tetapi jika bekerjasama dengan pedagang pakan tersebut akan disimpan untuk periode selanjutnya. biasanya yaitu kecil dari 30 hari. Panen dilakukan tepat waktu karena jumlahnya populasi ayam yang sedikit dan dilakukan bersama. Dikelola dengan jadwal yang tidak begitu ketat berdasarkan kesepakatan.
Sehingga pentingnya mengelola setiap faktor produksi dengan baik untuk mencapai efesiensi (Paradita et al.,2015; Ashari, 2016; Yunus, 2009). Umur panen lebih cepat yaitu kecil dari 30 hari dengan berat ayam kecil dari 1 kilogram.

Indikator pengelolaan uang dibutuhkan dalam menjalankan usaha ternak ayam broiler sesuai dengan Sudah ada yang melakukan pencatatan keuangan jika bekerjasama dengan poultry shop tetapi jika bekerjasama dengan pedagang pencatatan dilakukan secara manual dan mudah hilang. Peternakan pola mandiri memilki $t$ value $0,179<1,96$ yang artinya daya produksi pada peternakan pola mandiri berpengaruh positif tetapi tidak signifikan.

Nilai loading factor yang paling berkonstribusi pada daya produksi adalah pengelolaan uang (DYP4) dengan nilai loading factor 0,853 dan nilai $t$-value 2,356. Hasil penelitian ini sesuai dengan pe nelitian Burhanuddin (2014) menjelasakan pengelolaan uang merupakan salah satu indikator yang kuat dalam menjelaskan daya produksi dan didukung oleh penelitian Haliq (2017) dari hasil analsis yang dilakukannya yang paling besar membentuk karakteristik usaha yaitu pengelolaan uang.

Tabel 1. Pengujian hipotesa peternakan mandiri

\begin{tabular}{lllll}
\hline & Koefisien & T hitung & P Values & Keterangan \\
\hline $\begin{array}{l}\text { Daya produksi } \rightarrow \text { aktivitas } \\
\text { kewirausahaan }\end{array}$ & 0,028 & 0,179 & 0,420 & Tidak Signifikan \\
\hline Daya saing $\rightarrow$ aktivitas kewirausahaan & $-0,226$ & 1,643 & 0,101 & Tidak Signifikan \\
\hline Inovasi $\rightarrow$ aktivitas kewirausahaan & 0,368 & 2,996 & 0,003 & Signifikan \\
\hline
\end{tabular}

Keterangan: P-Values $<0,05=$ signifikan 


\section{Daya Saing}

Variabel daya saing merupakan variabel laten yang menggambarkan kemampuan usaha dalam meningkatkan daya saing usaha ternak ayam broiler agar usahanya mengalami kemajuan terhadap pesaingnya. Menurut Elitan (2002) bahwa pentingnya berkompeten dalam usaha untuk meningkatkan daya saing. Indikator ancaman pesaing (DYS2) menjelaskan perusahaan yang dapat mengendalikan produksi adalah poultry shop dan pedagang karena merupakan sumber modal peternak mandiri. Produksi usaha lain juga tidak terlalu berdampak kecuali pada waktu-waktu tertentu. Kreativitas sangat dibutuhkan dalam bertahan seperti menyediakan obat-obat alami guna kesehatan ayam dan hemat biaya. Indikator ini memiliki loading factor sebesar 0.538 yang artinya memiliki konstribusi terhadap laten daya saing karena kreativitas dibutuhkan dalam peternakan mandiri agar menggunakan sumber daya yang ada untuk hasil yang lebih maksimal dan pada peternakan mandiri tidak dibatasi dengan aturanaturan yang ketat. Hal ini sejalan dengan penelitian Jusni \& Mappigau (2012) bahwa kewirausahaan memberikan konstrbusi besar terhadap kreativitas dan inovasi.

Daya tawar pembeli (DYS3), Indikator ini memiliki nilai loading factor paling besar yaitu 0,844 yang dinyatakan valid, peternakan mandiri memilki daya tawar yang kuat karena pembeli menentukan cara pembayaran, menetapkan harga dan melakukan sortasi terhadap ayam yang akan dibeli. Hasil uji menunjukan hubungan variabel daya saing yang negatif dan tidak signifikan terhadap aktivitas kewirausahaan pada peternakan mandiri. Hal ini sesuai dengan penelitian Astuti (2016) bahwa daya saing memiliki pengaruh negatif.

\section{Inovasi}

Inovasi merupakan unsur yang penting untuk meningkatkan kemampuan bertahan, menghadapi persaingan bisnis dan pertumbuhan usaha. indikator penggunaan metode berproduksi baru memiliki nilai loading factor paling tingi 0,859 yang artinya memiliki kostribusi terbesar terhadap variabel inovasi, penimbangan ayam dilakukan per ekor jika penentuan harga dilihat dari berat ayam yang dipanen, tetapi pada peternakan mandiri terdapat beberapa peternak yang menentukan harga per ekor ayamnya, vaksin dilakukan dua tahap menggunakan ND dan IBD melalui vaksin tetes mata dan air minum. Pemeriksaan kesehatan juga dilakukan berkelompok. Indikator lainnya intensitas penelitian (INV2) dijelaskan memiliki loading factor 0,580 yang artinya dapat menjelaskan inovasi. Jika peternak belum mengetahui tentang pemakaian obat dan takaran pakan peternak bertanya kepada peternak lain selain itu, aktif mencari informasi baik melalui media maupun kesesama peternak. Melakukan pengamatan-pengamatan terhadap pakan dengan melihat dan membandingkan harga atau kualitas pakan yang akan digunakan. Mempelajari hal-hal terbaru seperti pembuatan obat-obat herbal yang digunakan untuk pengobatan ayam yang sakit dan dapat menghemat biaya. Terdapat beberapa manfaat obat herbal yaitu dapat meningkatkan daya tahan tubuh ternak terhadap stres dan penyakit, menekan mortalitas selama pemeliharaan dan ramah lingkungan (Desmayati, 2015). Sehingga perlu adanya penguatan kreativitas dan inovasi dalam melakukan kewirausahaan (Swathi et al., 2013).

Pada indikator pembukaan pasar baru (INV3) adalah aktivitas dalam memperluas jangkaan pasar berdasarkan kesukaan konsumen. Memiliki loading factor 0,577 yang artinya dapat menjelaskan inovasi. Pembukaan pasar baru ini dilihat dari melakukan penjualan keluar provinsi, meningkatkan produksi secara bertahap dan hanya memenuhi permintaan pelanggan. Pada peternakan mandiri memasarkan ayamnya keluar provinsi sampai ke pekanbaru dengan target pasar rumah makan dan restoran, memenuhi permintaan pelanggan dengan menyediakan sesuai dengan permintaan. Memiliki nilai $t$-value 2,976 lebih besar dari t-table $(1,96)$ yang artinya indikator inovasi terhadap aktivitas kewirausahaan berpengaruh positif dan signifikan. Peternakan pola mandiri memiliki nilai koefisien 0,368. Sesuai dengan penelitian Munyaka (2010) menjelaskan tantangan kewirausahaan salah satunya adalah pemasaran dan ketersediaan modal yang cukup.

\section{Pengaruh Kewirausahaan terhadap Per- tumbuhan Usaha}

Aktivitas kewirausahaan adalah segala kegiatan yang dilakukan dalam melakukan usaha untuk menambah nilai melalui penciptaan dan perluasan kegiatan ekonomi dengan mengidentifikasi dan memanfaatkan produk, proses atau pasar baru (Ahmad dan Seymor 2008). Proses menambah nilai pada peternakan mandiri terolong memiliki loading factor 0,745 yang artinya dapat 
menjelaskan aktivitas kewirausahaan. Pada mandiri panen ketika umur ayam kecil dari 30 hari sehingga ukurannya kecil karena pemasaran yang dituju adalah rumah makan dan restoran. Limbah ternak juga sudah ada yang dijual, tetapi sebagian besar menggunakan kembali untuk usahanya yang lain. Indikator aktivitas tim kerja menggambarkan aktivitas yang dilakukan oleh tenaga kerja maupun pemiliknya seperti me-nyediakan alat dan perlengkapan sesuai dengan yang ditetapkan oleh perusahan, menempatkan tenaga kerja sesuai dengan keahlian, menjalankan biosecurity, melapor secara periodik perkembangan budidaya ayam kepada perusahaan dan menjaga mutu ayam dengan menggunakan sapronak yang dipasok oleh perusahaan dengan jumlah dan tata cara yang telah ditetapkan. Indikator aktivitas tim kerja loading factor 0.719 yang artinya indikator ini dapat menjelaskan variabel aktivitas kewirausahaan. Menurut Ibourk dan Amaghoussl (2013) aktivitas kewirausaan signifikan digunakan dalam mengukur pertumbahan bisnis.

Pertumbuhan usaha memiliki dua indikator yaitu pertumbuhan tingkat pendapatan (PBP1) dan pertumbuhan skala usaha (PBP2). Kedua variabel manifestnya ini dapat menggambarkan variabel latennya pada peternakan ayam broiler. Indikator pertumbuhan usaha memiliki nilai loading factor 0,806 yang artinya berkonstribusi terhadap pertumbuhan usaha, indikator tingkat pendapatan penyumbang paling besar karena pembagian keuntungan pada mandiri ini dengan sistem bagi hasil dan sesuai dengan harga pasar yang berlaku pada saat panen. Sedangkan skala usaha rendah karena pada peternakan mandiri penambahan kandang dan tenaga kerja dilakukan jika memiliki modal yang cukup tinggi dan sesuai permintaan konsumen. Berikut adalah evaluasi model struktural peternakan mandiri dapat dilihat pada Tabel 2.

Pada peternakan pola mandiri didapatkan nilai $t$-value 2,811 lebih besar dari t-table 1,967 dan memiliki nilai koefisien 0,330 yang artinya setiap kenaikan satu persen variabel aktivitas kewirausahaan maka akan meningkatkan pertumbuhan usaha sebesar 33 persen. Variabel laten aktivitas kewirausahaan pada peternakan pola mandiri berpengaruh positif dan signifikan terhadap pertumbuhan usahanya. Hasil penelitian ini sesuai dengan penelitian Astuti (2016), Burhanuddin (2014) dan Sari (2015) bahwa aktivitas kewirausahaan berpengaruh positif dan signifikan terhadap pertumbuhan usaha. Hal ini karena korelasi positif antara aktivitas kewirausahaan dan pertumbuhan usaha menunjukan bahwa semakin tinggi tingkat aktivitas kewirusahaannya semakin tinggi pula pertumbuhan usaha. Aktivitas usaha yang didukung dengan adanya inovasi pada usaha peternakan ayam broiler pola mandiri.

Tabel 2. Evaluasi model struktural (path coefficient) pada pola usaha ternak ayam broiler di Kabupaten Lima Puluh Kota

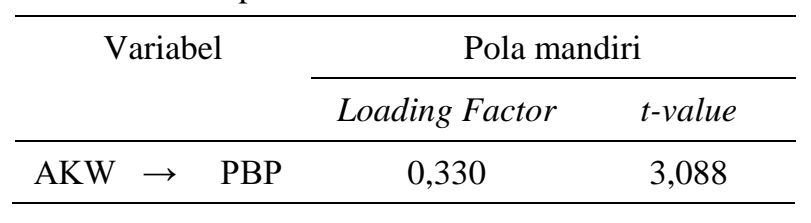

\section{KESIMPULAN}

Peternakan pola mandiri daya produksi berpengaruh positif dan tidak signifikan, daya saing berpengaruh negatif dan tidak signifikan terhadap aktivitas kewirausahaan. Sedangkan pada variabel inovasi berpengaruh positif dan signifikan yang paling dominan berkonstribusi adalah penggunaan metode berproduksi baru. Variabel aktivitas kewirausahaan peternakan pola mandiri berpengaruh positif dan signifikan terhadap pertumbuhan usaha. Hal ini menunjukkan bahwa aktivitas kewirausahaan berperan penting dalam peningkatan pertumbuhan usaha ternak broiler pada pola mandiri.

\section{DAFTAR PUSTAKA}

Ahmad, N., R.G. Seymour. 2008. Defining entrepreneurial activity: definitions supporting frameworks for data collection. Paris: OECD Series: OECD statistics working papers (1):3-18

Ashari, L. 2016. Pengaruh praktik manajemen sumber daya manusia terhadap produktivitas karyawan peternak ayam potong PT. Mitra Gemuk Bersama (MGB) di Kabupaten Jember. Jurnal Ekonomi dan Bisnis GROWTH 14(2):72-82.

Astuti, R.P. 2016. Pengaruh Aktivitas Kewirausahaan Terhadap Pertumbuhan Usaha Peternakan Ayam Broiler di Provinsi Jambi. Thesis. Sekolah Pascasarjana Instritut Pertanian Bogor. Bogor. 
[BPS] Badan Pusat Statistik. 2017. Populasi dan Produksi Ayam Broiler di Sumatera Barat Tahun 2016. Badan Pusat Statistik Sumatera Barat. Padang.

[BPS] Badan Pusat Statistik. 2017. Pola konsumsi makanan penduduk Provinsi Sumatera Barat. Badan Pusat Statistik Sumatera Barat. Padang.

Burhanuddin. 2014. Pengaruh Aktivitas Kewirausahaan Peternak Ayam Broiler Terhadap Pertumbuhan Bisnis Peternakan di Indonesia. Disertasi. Sekolah Pascasarjana Institut Pertanian Bogor. Bogor.

Bygrave, W.D. \& A. Zacharakis. 2010. The Portable MBA in Entrepreneurship: Fourth Edition. John Willey \& Sons Inc. New Jersey.

Desmayati. 2015. Pemanfaatan Herbal untuk Meningkatkan Daya Tahan Tubuh ayam. Balai Penelitian Ternak Kementrian Pertanian. Jakarta.

Dinas Peternakan dan Kesehatan dan Kesehatan Hewan Kabupaten Lima Puluh Kota. 2017. Jumlah peternak ayam broiler di Kabupaten Lima Puluh Kota. Kabupaten Lima Puluh Kota.

Ellitan L. 2002. Praktik-praktik pengelolaan sumber daya manusia dan keunggulan kompetitif berkelanjutan. Jurnal Manajemen dan Kewirausahaan 4(2):65-76.

Faturohman, M., Purwanto, A. Nugroho, \& Suharyadi. 2007. Kewirausahaan. Salemba Empat. Jakarta.

Ghazali, L., \& H. Latan. 2015. Partial Least Square Konsep, Teknik dan Aplikasi Menggunakan Program Smart PLS 3.0. Penerbit Universitas Diponegoro. Semarang.

Haliq, I. 2017. Pengaruh orientasi kewirausahaan terhadap kinerja usaha peternakan ayam broiler di Kabupaten Bogor. Disertasi. Sekolah Pascasarjana Institut Pertanian Bogor. Bogor.

Ibourk, A. \& J. Amaghoussl. 2013. Entrepreneurial activities, innovation and economic growth: the role of cyclical factors. International Business Research 6 (1):1913-9004.
Jusni, Mappigau. 2012. Enterpreneurial quality of smale scale (SMEs) broiler farming with independent business model in Maros District of South Sulawesi Provincy Indonesia. International Journal of Business and Social Science 3(6):74-81.

Kritikos, A.S. 2014. Enterpreneurs and Their Impact on Jobs and Economic Growth. DIW Berlin University of Postdam and IZA Germany. Germany.

Munyaka, G.F. 2010. Factors Affecting the Performance of Small and Medium Scale Polutry Farming Enterprises in Karuri Kenya. Thesis. University of Narobi. Kenya.

Naude, W. 2008. Entrepreneurship in aconomic development. Journal of Economic Literature 2008(20):1-45.

Okpara, F.O. 207. The value of creativity and innovation in enterpreneurship. Journal of Asia Enterpreneurship and Suistainability. 3(2):1176-8592.

Pambudy R. 2010. Membangun Entrepreneur Agribisnis yang Berdayasaing. Di dalam: Orange Book 2: Kewirausahaan dan Dayasaing Agribisnis. Editor Baga, L.M., A. Fariyanti. \& S. Jahroh. Penerbit IPB Press. Bogor.

Paradita, D., W. Sarengat, \& M. Handayani. 2015. Efesiensi produksi peternakan ayam pedaging Riski Jaya Abadi Kebumen ditinjau dari efesiensi manajemen, teknis, dan ekonomis. Animal Agriculture Journal 4(1):75-80.

Sari, S., W.B. Priatna, \& Burhanuddin. 2015. Pengaruh aktivitas wanita wirausaha terhadap pertumbuhan usaha olahan kentang di Kabupaten Kerinci Jambi. Jurnal Agribinisnis Indonesia 3(1):39-54.

Se Board Performance Committe. 2008. Enterprise and Economic Growth: Industry and Policy. Scottish Enterprise. Scotland.

Stough, R.R. 2016. Entrepreneurship and regional economic development: some reflections. Investigaciones Regionales-Journal of Regional Research 36:129-150. 
Swathi, A., M.M. Krishna, \& R.R. Babu. 2013. Role of creativity and innovation in enterpreneurship. Innovative Journal of Business and Management 2(5):112-115.

Tamalluddin, F. 2012. Ayam Broiler 22 hari Panen Lebih Untung. Penebar Swadaya. Jakarta.
Yunus, R. 2009. Analisis Efesiensi Produksi Usaha Peternakan Ayam Ras Pedaging Pola kemitraan dan Mandiri di Kota Palu Provinsi Sulawesi Tengah. Thesis. Universitas Diponegoro. Semarang. 